\title{
RELIGIO-CULTURE, FEAR, AND ZIMBABWE'S LEADERSHIP PERCEPTIONS
}

\author{
Muchumayeli Bhebhe* \\ University of Zimbabwe \\ 'Africa will rise or fall on the quality of its leadership.' \\ -Kenneth Kaunda
}

\begin{abstract}
The study is a response to the call for papers on African issues and discusses the notion of leadership in the Zimbabwean context. Based on material drawn through an interdisciplinary research process, this article argues that the phenomenon of fear emanating from a Zimbabwean religio-culture cuts across the country's socio-political structures and affects its different forms of leadership. Therefore, by drawing on primary and secondary as well as literary and non-literary, sources, the article examines how and why religio-culture and especially its elements, such as the phenomenon of fear, continue to influence the people's understanding of leadership. The quest for a cross-cultural perspective leads to the consideration of both African and non-African scholarly views. In order to draw on concrete data, I focus on the perceptions and experiences of ordinary citizens whether professionals or non-professionals. Furthermore, the study considers arguments and propositions from disciplines such as history, political science, religious studies, anthropology, and African philosophy, among others.
\end{abstract}

KEY WORDS: fear, religio-culture, leadership, Zimbabwe, spirituality

\section{Introduction}

Through research and personal experience, I have discovered that many Zimbabweans ${ }^{1}$ relate to leadership_-both formal and informal-in a way

* MUCHUMAYELI BHEBHE (PhD 2009, University of Zimbabwe) is doctoral candidate in Leadership Studies at Franklin Pierce University in Rindge, New Hampshire, United States of America. Email: ishmb@yahoo.com.

1 Zimbabwe is a landlocked country located in the Southern part of Africa, and shares borders with South Africa, Botswana, Zambia, and Mozambique. In 1980, she regained independence from the British colonial government which began in the 1890s. Zimbabwe's area comparative to that of the United States is slightly bigger than the state of Montana. The total area of Zimbabwe is $390580 \mathrm{~km}^{2}$ with land approximated at only $386670 \mathrm{~km}^{2}$ and water at only $3910 \mathrm{~km}^{2}$. The population estimate of Zimbabwe is over 12 million, precisely 12746 990. The official language in Zimbabwe is British 
that manifests features from the society's religio-culture, for example 'fear'. In Zimbabwe, there is much fear especially the fear of death, fear of serious illness, fear of mystical powers, including the fear of people in positions of authority, etc. As will be shown below, the Zimbabwean 'heritage is intensely religious' (Gordon 2002:158) and religion continues to influence the people's interpretation of reality. A 'religious perspective' (Geertz 2000:112) continues to shape 'the software of the people's minds' and it 'colors their view of reality' (Ellis and Ter Haar 2004:15) including their perceptions of 'leading' and 'following'. For this and many other reasons, I wish to demonstrate the connection between formal and informal leadership, in light of several features of religio-culture and the phenomenon of fear. Ultimately, the study will focus on charismatic authority, which I identify as a theory matching both the context and the leadership elements that will be uncovered in this article. I shall attempt to demonstrate how charismatic authority influences the nature and outlook of Zimbabwe's political leadership.

However, I would suggest that the presence of fear connected to leadership and various other cultural features that are usually judged by outsiders and non-members 'as negative' could be a part of the people's 'covert culture' (Bowron 1957:4). According to Purdon (2011:1), covert culture consists of 'a recurrent pattern of inconsistent or seemingly illogical behavior' which members of a society consciously or unconsciously show no matter how much they try to deny or suppress it in some instances. Purdon (2011:1) illustrates his definition of covert culture with the case of a person who says, 'Smoking kills; I want to remain alive; I want to smoke'. It seems that some modern day Zimbabweans deal with the phenomenon of fear associated with leadership in this manner. Not many will admit that they use fear, terror, and cohesion in their leadership role but in real life, they do. However, the situation today is different from the (pre)colonial past when some African leaders such as King Shaka of the Zulu and Lobengula of the Ndebeles were celebrated for using fear as tool of leadership. In those days, it was normal for people to talk about the 'fear of the king', 'fear of a husband' or 'fear of parents' in the society. Today, only few people would admit that they lead homes, colleges, companies or even the nation by inducing fear on their subjects or followers.

Nonetheless, one can actually tell that both positive and negative religiocultural features are at play by paying attention to the pragmatic 'leaderfollowers exchanges' (Messick 2005:82). Daily transactions between actual leaders and followers especially the way some instructions are given and followed or expected to be followed, what people say and do not say in the

English while the local languages taught in schools in most parts of the country are IsiNdebele and ChiShona which share the same alphabet with the English language.

PERICHORESIS 14.1 (2016) 
presence of leaders or followers, and how people relate with one another as leaders or followers could also point to religio-cultural features. Although it may appear at first that both leaders and followers benefit from the use of fear in the Zimbabwean culture, concrete evidence shows that people in leading positions are its major beneficiaries while followers are usually victims, as will be discussed later in this essay.

Following an interdisciplinary research process that relies more on a qualitative analysis of concrete and other primary and secondary sources from the social sciences and humanities, this study will discuss how and why religio-culture especially the element of fear impacts leadership views and opinions of the Zimbabwean people. The interdisciplinary approach will be employed because the issues raised here are complex and so engrossed in the labyrinth of culture that no single linear method can address them adequately. An interdisciplinary research process in this article refers to the 'process of answering a question, solving a problem, or addressing a topic that is too broad or complex to be dealt with adequately by a single discipline and draws on disciplinary perspectives and integrates their insights to produce a more comprehensive understanding or cognitive advancement' (Repko 2008:12).

To achieve the goal of the study therefore, I have collected data from various sources and across relevant academic disciplines such as history and historiography, religious studies, phenomenology, cultural anthropology, sociology, political science, psychology, and philosophy. The method of interdisciplinary integration is employed to put together what is considered relevant to this article. Included in the discussion are views and practical experiences of the everyday people of Zimbabwe. It is my assumption that there is a great deal of wealth and knowledge across all social sections of the Zimbabwean society whether in high or low social positions. The study also touches on charismatic authority as one of the emerging themes from the discussion and highlights the case of president Robert Mugabe by way of illustration.

\section{Religio-Culture and Zimbabwe}

The term 'religio-culture' which compounds the words religion and culture is employed here to describe the 'way of life' in the Zimbabwean society which shows that the people's lifestyle is intensely steeped in religious material. In this article, tentative definitions of culture and religion are employed mainly as tools of research. The term culture refers to every part of human life including what Hofstede describes as the "collective programming of the minds which distinguishes the members of one group or category from another' (Hofstede 1991:5). This definition is considered important because it clarifies that culture is not just 'what we are as people' 
(Boon 2007:4), it is also, more importantly, something learned and programmed into us by who and what surrounded us when we were born; hence culture is adaptable.

On the other hand, religion is defined as, 'a system of beliefs and practices pertaining to things sacred' (Chitando 2008:22) or as, 'a belief in the existence of an invisible world, distinct but not separate from the invisible one, that is home to spiritual beings with effective powers over the material world' (Ellis and Ter Haar 2004:14). These definitions are pertinent here because they show what is relevant to the Zimbabwean culture such as the fact that the spiritual has a bearing on the physical and there is a continuous give-and-take relationship between the two worlds. In other words, as the praises and venerations go up to the spiritual realm, blessings are expected to come down; but when deviation, wrongdoing and neglect characterize the physical world, then withdrawal and punishment will surely be expected by those in the material world. Most importantly, in Zimbabwean culture there is "no formal distinction between the sacred and the secular, between the religious and the non-religious, between the spiritual and the material areas of life' (Gordon 2002:159), but religion permeates every part of life including leadership.

In Zimbabwe, numerous religious traditions ${ }^{2}$ compete for followers such as the African indigenous religion(s), Christianity, Islam, Hinduism, Buddhism, the Baha'i Faith, and many others; in fact the expression 'Africa's rainbow of religions' suits this context (Platvoet 1996:47). All these different belief systems generally seek to offer the members of the society a 'world to live in' (Geertz 1973:87). Jacob Olupona confirms that religion is the 'pulse of the Africans' private and public lives' (Olupona 2014:2). And even though one may choose other religions such as Christianity or Islam, with indigenous religions, everyone is 'believed to be born in to his or her religion just as one is born into one's family and culture' (Ndlovu 1991:29). Moreover, with the amount of religious materials that flood people's lives today, it is appropriate to say that 'it is largely through religious ideas that [Africans] Zimbabweans think about the world today' (Ellis and Ter Haar 2004:2). 
Hence, as most indigenous people "continue to perceive, interpret and find meaning about the world and reality through some religious "spectacles"، (Bhebhe 2013:11), one could also argue that religio-cultural values influence leadership, especially how it is perceived and practiced in the Zimbabwean society. The 'religious modes of thinking about the world' have become a part of everyday life including the way people lead and follow (Ellis and Ter Haar 2007:385).

To show that religio-culture has always influenced the socio-political leadership of Zimbabwe, I will consider some political figures in the period of Zimbabwe's independence who were also religious people. When Zimbabwe attained independence in 1980, the late reverend Canaan Sodindo Banana, a minister of the Methodist Church, became its first president and he ruled the country until 1987. During this period, Robert Mugabe was the prime minister. Since Banana was a religious leader and a political figure, his view of leadership must have been influenced by both religio-culture and politics. Banana's leadership came soon after that of bishop Abel Muzorewa who between 1978 and 1979 was the leader of a short-lived unity government that included the former colonialist Ian Smith as a minister without portfolio and chief Chirau from Zvimba as one of the senators. Before that period, reverend Ndabaningi Sithole was very active in the war of liberation.

Later, president Robert Mugabe who was born at a Catholic mission station in British-ruled Southern Rhodesia became the country's president. Mugabe attended Jesuit schools and he still professes Catholicism, attends masses in Harare from time to time, and is one of the few privileged people that can freely go in and out of the Vatican. By virtue of his upbringing in a Catholic tradition, it could be assumed that some of his views of leadership would be very much influenced by his religious beliefs which are rooted in both Catholicism and African indigenous religions. For instance, following his stance against gay practices and lesbianism, during one of his election campaign speeches, Mugabe criticized bishop Desmond Tutu of South Africa 'for interpreting the Bible wrongly by supporting homosexuality'. Mugabe said that 'when you are a bishop and cannot interpret the Bible, you should resign and give it to those who can. We will not compromise our tradition and tolerate homosexuality' (Ndlovu 2013). By publicly speaking against homosexual practices as well as criticizing a bishop who supports this practice, Mugabe may have tapped into his knowledge of Catholicism, African indigenous religions, and indigenous culture. Furthermore, by issuing such statements during a campaign rally, he probably judged that his speech could earn him political mileage among Zimbabwe's citizens.

The above examples suggest that indeed religio-culture affects the political leadership of Zimbabwe. The next section will focus on the relationship 
between Zimbabwe's religio-culture and the local perceptions about leadership.

\section{Religio-Culture and the Zimbabwean View of Leadership}

Based on the premise that 'the way we see things is affected by what we know or what we believe' (Berger 1972:8), in this section parallels will be drawn between some aspects of Zimbabwean religio-culture and the form, function and practice of leadership in this society. As Bennis (2007:15) has observed, 'leadership affects the quality of our lives as much as our in-laws or our blood pressure', hence the study of leadership is imperative. Leadership also refers to a dynamic 'process whereby an individual influences a group of individuals to achieve a common goal' (Northhouse 2010:3). This way, 'both leaders and followers are involved... and both need each other' (Northouse 2010:3). In other words, leadership involves a 'mutual, leaderfollower relationship in which both the leaders and the followers contribute and benefit from it' (Bhebhe 2014:1). As such, leadership is ideally not a process that focuses on either leaders or followers but on both-including every other equipment (clothing, mode of transport, time, chair, office, etc.) that enables leadership to be a fruitful process.

However, without necessarily undermining the dynamism of the society and the freedom of its members, it is important to note that from the period before, during and after the-colonial era, the people of Zimbabwe have always worked under some form of leadership. Most people also participate in society as either leaders or followers beginning with the families, villages, communities, schools, to the highest ranks of political leadership, but much of this has always been connected to the prevailing religio-culture. Since time immemorial, leaders were expected to help maintain peace, order, and security in society as well as instill a sense of direction in unruly individuals. The inherent communitarian aspect of the society has made it imperative for people to always work and play at least with some form of formal or informal leadership structure. And the idea of groups has been enhanced by the fact that the Zimbabwean people are generally driven by values expressed in sayings such as, 'I am because I belong, alone I am a beast' or the Shona adage, Munhu munhu pamusana pevanhu ('A person is a person because of other people'). Such beliefs about life have made leadership a necessity and not an option in almost every part of the society. This reality has also contributed to the inevitability of charismatic authority since from time to time especially during crises some people rise up as leaders to give vision and a sense of direction to the people. The idea of charismatic leadership will be considered more fully below, but the next section will focus on the notions of hierarchy and power. 
Leadership Hierarchy and Power

The general structure of local leadership has always been inherently hierarchical. Dusing $(2000: 1,70)$ notes that, 'in pre-colonial Southern Africa, traditional leaders [are] personified within the different levels of hierarchy (like local communities, chiefdoms, kingdoms or states) the central political, economic, social, judicial and religious authority'. However, even within some modern hierarchical leadership structures found in Zimbabwe, the person at the top or 'in front' in the leadership chain is usually 'the sole decision maker and goal-setter' in a typical top-down relationship in which 'followers are subordinate to the leader (who) is strong in vision, discipline and action' (Simpson 2010:3). The abovementioned powerful 'role was not necessarily authoritative' (Dusing 2000:73) in the traditional society as most leaders worked in consultation with advisors even though they remained the custodians of the final say or action in the decision-making process. At times, the advisors only operated more as a part of the leader's thinking process, and at most, they acted merely as the mouthpiece of the leader to the people or vice versa. This way, the hierarchical structure of leadership was not compromised.

In Zimbabwe, various terms from the local languages which describe and celebrate the 'act of leading' indicate that leaders are elevated above their fellow group members. Some of these terms include mutungamiri/umkokeli (Chishona/IsiNdebele) meaning 'the person who shows the way or walks in front'; umpatintambo (IsiNdebele), that is, 'the person who holds the front leash pulling everyone forward'; and mukuru wepano (ChiShona), 'the big person in charge'. Others are changamire/inkosi (ChiShona/IsiNdebele meaning) 'lord', and 'varipanyanga', a local slang which means 'the one holding the 'horns' (nyanga) of leadership'. With all these names, the leader is celebrated as the one stationed at the pedestal of leadership with followers regarded as standing behind, in line or under a leader's headship, superiority, and power.

Depending on the level of a leader's sphere of influence, for instance as a soccer coach, a boarding school principal, a minister of religion, a chief or headman of a village, the executive president of the nation, etc., every leading position does 'wield power' (Bennis 2007:4). And by virtue of holding a leading role or position, many leaders have power to reward and punish their subordinates depending on how they fulfil the predetermined expectations which are sometimes based on the particular leaders' opinions, moods, personal preferences, and above all, the prevailing stereotypes and norms of the society. Thus, to some extent, each leader's style conforms to the saying, 'power corrupts and absolute power corrupts absolutely' (Boon 2007:76) because when perceived as mukuru (the big person), it means they 
have access to resources that can be used to issue threats and restrictive orders which could make the lives of the followers miserable.

Moreover, in a bid to amass more leadership power, leaders in this culture are reported to have gone to the extremes of using mystical and magical concoctions which are at times mixed with oil extract from snakes and crocodiles or lions' fat (mafuta eshumba). With these, they would smear their foreheads every morning so that each worker who sees them would run. This way, the leader secures absolute control over the followers; and in the workplace, the subordinates would always defer to the leader even before he or she utters a word.

However, it is pertinent to note that in Zimbabwe, a wide gap exists between leaders and followers which can be attributed to society's 'high power distance' (Hofstede 1984:1). Geert Hofstede who coined the term power distance describes it as 'the degree to which members of a society accepts an equal distribution of power' (Hofstede 1984:1; Adler 2013:39). Therefore, in most of the formal and informal sectors of the society, there is a wide chasm of power inequality between people in leading positions and those following them. Some leaders are sometimes very powerful and their positions are so life threatening that some subordinates would rather deal with mediators (deputies and other senior workers) than deal directly with the person in charge. One Zimbabwean, Machingura (2012:1), describes the extent to which some leaders are elevated in this society. He notes that, 'rulers are put as caring omnipotent fathers who must always be obeyed and not questioned such that raising a hand or a foot or a tongue against them becomes taboo' (Machingura 2012:1).

The power disparity between followers and leaders would also make it imperative for followers to address leaders by prefixing their surnames with honorific titles or even credentials such as doctor, professor, elder, vicechancellor, chief, president, etc. On the contrary, followers are at times merely viewed as subordinates referred to by terms such as povo (masses) or vanhu (people), vashandi (workers), and when lucky, some would only be respected due to their age or marital status, and their names may be prefixed with, $\mathrm{Va}$ - (which stands for Mr or Mrs). In most work environments, the power-distance makes it unacceptable and difficult for followers to challenge authority and, they often 'have much less input into the way they perform their work' (Adler 2013:40). The role of followers is simply to follow.

In some situations which two leaders share similar leadership roles or offices, or even work side by side, the inherent structure of hierarchy and the subject of power take precedence and one may end up usurping all the power thereby relegating the other to a lower position. In one incident, two Zimbabwean based religious NGOs with some sponsors from the United States of America, merged in 2008. The man who was the CEO of company

PERICHORESIS 14.1 (2016) 
A (Benson, not his real name) became the director and another man from company B (Dickson, not his real name) became the deputy. However, after a few months, Dickson wanted to resign because he felt useless and unwanted. On several occasions Benson had told him to keep his ideas to himself because 'Hakuna musha unana baba vaviri' ('There is no home with two fathers') and because 'a snake with two heads is fake'. He meant that only his ideas and influence were important for the success of the organization. In fact, in an informal discussion I had with him, Dickson reported that at one time Benson told him openly that his job as a deputy was to 'hold the ladder for Benson to climb up securely' meaning he was only there as a scaffold to his colleague's mission and dream and not as part of the dreamers. In other words, as a deputy, Dickson's colleague did not expect him to give suggestions but just follow his lead.

However, the dynamics of hierarchy and the power associated with leading and following across the different socio-political structures in Zimbabwe coincide with the indigenous worldview that is very much pollinated by religio-culture. Naturally, Zimbabweans subscribe to a tripartite cosmos where at the apex of existence there is the spiritual world above (kumusoro kudenga), which is the abode of the Supreme Being, who is known by various local names such as Mwari (God), Musikavanhu (Creator of People), Unkulunkulu (the Creator God), and Usomadhla (the all-powerful one), among others. It is believed that this mighty deity possesses absolute power and that below the deity, there are ancestral spirits, vari kumhepo (the ones in the air) which act as mediators or links between God and humanity. In addition, human beings, animals, and plants live in the physical world (panyika) where they receive orders, and also rewards or punishments from the spirits above, depending on their actions. There is also an underworld (pasi penyika) believed to be the abode of a myriad of spirits, both good and bad. Such spirits can facilitate benefits from above or they can be manipulated to harm one's enemies. In other words, the spirits can be used by people either for good or bad purposes; and these include strange spirits (mashave) ${ }^{3}$ as well as spirits used for witchcraft and sorcery purposes.

Similarly, because of the belief that God is the highly elevated deity that can be approached mainly via intermediaries such as ancestors and Jesus Christ, many Zimbabwean leaders prefer to be approached through their subordinates. For instance, in the formal sector, many executives are approached via receptionists and secretaries, while in the informal sector, trahomes and did not receive proper burial and funerary rites. As a result, they find people to possess and empower with different skills such as the ability to hunt, dance, etc. in areas close to where they died or where they were probably buried. 
ditional leaders and chiefs are accessed via their aids or some other members of the advisory council in the same way that some fathers are approached in their families through their wives (mothers).

A practical example can be drawn from the act of paying lobola (a token of appreciation which is part of the marriage rite in Zimbabwe). Among the Zezuru people of Zvimba in Zimbabwe, the suitor cannot come directly to make payments to his future father-in-law but has to go through a mediator (known as munyai, sadombo or samutumwa). Without this intermediary, the formal process cannot be completed. During the negotiations, the oldest member of the family, the family head, will not respond to any of the requests from the intermediary until his juniors observe the protocol, for instance, by asking, 'Murikuinzwa here iyo Gushungo?'4 meaning, 'Gushungo, what is your opinion in this matter?' or 'Gushungo, can you hear what our guest is asking for?' The elder may then respond 'Iri munzeve' (I can hear very well), and all his responses would follow the same channel until word gets to the mediator who would then inform the real suitor. At this point, the suitor is not welcome to witness the actual proceedings, until he is ceremonially invited at the end of all the negotiations.

Moreover, in most traditional families, the father-in-law and mother-inlaw remain distant from the prospective son or daughter-in-law, who is expected to bow down or kneel before them (unless it is against a particular family's norms) to show respect and gratitude. In this culture, it appears that one remains indebted to the in-laws for the rest of one's life, probably because one has been given their child in marriage. Therefore, one would have to pay homage to them as if they were gods or ancestors of sorts.

However, because some leaders are very much elevated to the position of the Supreme Being or spiritual beings, they end up presenting themselves as demiurges. In the past, some have gotten to the point of becoming 'coercive-in that they would demand compliance in the fashion [do what I tell you'] (Goleman 2000:82) or give me what I want when I want it, and so on.

\section{Sacredness of Leadership}

In Zimbabwe, there is also the inherent belief that leaders in the traditional sense influence both the secular and religious domains of life (cf. Olupona 2014:38). For instance, chiefs are said to 'possess mystical, life-sustaining powers, with their own well-being intimately intertwined with the well-being of their people, lands and institutions' (Olupona 2014:38). Therefore, in the traditional sense, leaders are to be obeyed because of their office or position, what they possess, and what they bestow; 'they must always be obeyed 
and not questioned such that raising a hand or a foot or a tongue against them becomes taboo' (Machingura 2012:20).

Additionally, parents, in addition to being providers and pacesetters in the home, are also believed to hold keys and powers to either curse or bless their children. If children show any signs of rebellion, parents have the power to curse them even up to the point that they become lunatics for life. In fact, among the Shona people of Zimbabwe, children must not provoke their mothers neither should they rebel, beat up their mothers or allow them to die in anger. The Shona people say, unopara ngozi (will invite the wrath of the avenging spirits upon oneself). If that happens, the child could be tormented by evil spirits for the rest of his/her life or even go mad. Thus, in some families, such beliefs cause children to be submissive to authority even before they leave home.

Submission to authority is often connected to threats such as, "you will see'; 'Vachauya baba vako' (Your father is coming); or 'I will chase you out of my land'. The threat may work as long as the leader is in charge but when he or she dies or when those being threatened relocate to another place, then, these are free to return to their old ways. This form of leadership is usually connected to hypothetical statements such as if you respect your leaders then you will not be cursed' or 'if you do not obey then you will be punished'. Although the method might work for a while in this particular context, I believe it cuts away from the independent virtue of learning to obey one's leaders because it is a good practice.

\section{Witchcraft and Sorcery}

Accordingly to Olupona, 'in Africa, witchcraft is almost universally defined as the manipulation of occult forces to do harm and achieve selfish ends' (Olupona 2014:50). This goes hand-in-hand with the description of witchcraft as 'the ability to inflict damage by occult means, that is, to mysteriously (non-naturally) injure other people' (Hallen and Sodipo 1997:88). This phenomenon is very common especially among the older generation of Zimbabweans most of whom grew up in circumstances where witchcraft and sorcery were the driving force in many action and decision taking. To this day, belief in witchcraft and sorcery continues whether directly or indirectly to drive the way some people participate in the 'leader-follower exchanges' both in the social or formal settings, from the most remote villages to the most sophisticated cities.

The Zimbabwean society makes a distinction between witchcraft and sorcery. Witchcraft is believed to involve mystical powers, spirit possession and people meeting 'late at night when they go about naked to perform their nefarious deeds, acting together in cultic collusion' and the eating of human flesh (Bourdillon 1998:175). Sorcery, on the other hand, is thought to be 
the intentional manipulation of physical objects, plants, animals or even weather (to create lightning) and to cause harm to others. However, nowadays there are various versions of witchcraft and sorcery, which employ modern technology in the form of TV or computer screens to track down victims before striking them. In some cases, poisonous chemicals including DDT or auto-vehicle coolant may be administered in people's food or drink in order to harm them.

One interview respondent who is a primary school teacher in the Zvimba area of Zimbabwe narrated how one school headmaster from their area was exposed by a group of witch-hunters called tsikamutandas $^{5}$ (literally 'step on a magical stick and we will tell whether you are a witch or not'). The headmaster was accused of possessing potent charms that made him to be feared by both the students and teachers, and which he also used to harm his adversaries (Skype Interview, September 2013). Such phenomenon is common in different areas of the Zimbabwean society. From personal interactions and participant observations, I have heard of cases in which husbands would acquire herbs and concoctions called runyok ${ }^{6}$ to 'lock' their wives secretly so that no one else could have sex with them and live. Some wives also use mupfuhwira (love potion or charms), to prepare food for their husbands (and sometimes for their children) to render them docile, fearful and easy to manipulate.

Nowadays, some chief executive officers of big companies, supervisors at local farms or some founders of churches also use witchcraft and sorcery to achieve their end. For instance, many people suspect that a self-styled and popular prophet Emanuel Makandiwa, who is the founder of a fast-growing Pentecostal group called the United Family International Church (UFIC), is somehow connected to mystical powers and possibly to the practice of witchcraft and sorcery. It is claimed that he performs miracles such as increasing people's height, making people lose weight instantly, and enhancing the size of penises. He was reported to have performed a penisenhancing miracle on a man from Namibia at a 2014 New Year's Day service in Harare, but the man's penis continued to grow bigger and would not stop (Machirori: Nehanda Radio, April 20, 2014). Thus, if a leader possesses powers to do such unnatural things, it may not be easy for the followers to challenge his or her opinions for fear of what the leader could do to them.

Tsikamutandas is a group of self-proclaimed witch-hunters that go around the country presumably to 'cleanse' homes and villages of witches. 
Moreover, many Zimbabweans take it for granted that most political leaders have regular consultations with prophets, witches or diviner-healers so that people would vote for them or they could continue to stay in power. Sometimes, people say that a particular politician has his or her own personal traditional diviner-healer (ane n'anga yake), who helps him/her to get the people's votes and with powers to punish rivals. Some leaders even seem to have professed their belief in 'mystical powers' that could be used to harm others. For example, it was reported that after the death of three of his close colleagues in 2001, Emmerson Mnangagwa, the Speaker of the Zimbabwean Parliament, said: 'We do not know what is hitting us; it is not natural. We fear the hand of Lucifer is at work' (Ellis and Ter Haar, 2004:85). His concern confirms two indigenous views-first, behind some physical deaths are some harmful spiritual forces usually sent by human enemies, notably, witches, and second, even the country's political leaders believe in such powers.

During social interactions, I have often heard people say, 'Mukuru wedu isu akaromba haupikisane naye', meaning 'our leader is surrounded by magical stuff and no one dares to challenge him or her'. In some cases, some people may turn down promotions because of the belief that they might be killed through witchcraft by their rivals. Consequently, sometimes leaders may exploit this mindset and present themselves as indeed being surrounded or fenced by mystical powers even when in fact they are not. This attitude is not surprising because at times some political figures seem to follow the Machiavellian maxim, 'It is better to be feared than loved', even though most of these leaders would rather be both 'feared and loved'.

\section{Fear and Leaders}

Closely linked to witchcraft and sorcery is the notion of fear. While in the middle of a crumbling economy and other hard experiences such as HIV/AIDS, starvation and about 80 percent unemployment rate, many Zimbabweans also live in constant fear. Most people fear different things including death, illness, accidents, angry spirits, and dangerous animals such as snakes. Above all, there is the inherent fear of other people. Among the most feared people are those who possess mystical powers such as people who practice witchcraft and who perform miracles as well as some people who play leading roles both in formal and informal sectors of the society. Actually, Hare $(2003: 23,32)$ has noted that 'fear is an aspect of leadership that is all-too-often ignored' and this is a mistake one would not like to make in this study. 
The lexicon of the VaShona ${ }^{7}$ people of Zimbabwe contains separate words for fear (kutya) and respect (kukudza), but in real life application, these two words carry similar meanings. In fact, the Shona word for respect connotes fear and when people say ' $k u d z a$ vakuru vako' (respect your leaders), in essence they mean 'itya vakuru vako' (fear your leaders). Thus, the two statements are used interchangeably. However, the meaning of kukudza (respect) is associated more with 'reverence; having a reverential awe of; venerate' (Shona Dictionary 2014), and when given a chance to lead or follow, people in this society naturally apply every other available definition of fear.

For the purposes of this study, I shall adopt Karen Evenson's definition of fear as 'the powerful feeling of alarm, distress, or apprehension caused by the expectation or perception of danger, pain or disaster' (Evenson 2004:1, 13). Closely related to Evenson's is the definition by Sarah Laing, who sees fear as a concern regarding danger or threat to survival' (Laing 2009:352). Although fear might cause anxiety among its victims, the two are not synonymous. Accordingly, Gerald Suarez affirms that 'most psychologists agree that fear is a response to a clearly identifiable and circumscribed stimulus' while anxiety is 'a response to an unclear or ambiguous stimulus' (Suarez 1993:1). In other words, fear is very much connected to experience and possible consequences and it is not just about being anxious, phobic or timid. Hence, people may be fearful of a leader for instance, because they have witnessed or heard about the way that headmaster, father-in-law, CEO, or president dealt with a fellow subordinate.

To a certain extent, most Zimbabwean leaders are feared in the society. For instance, in some traditional families, children may fear their fathers to the point that their mothers may have to act as mediators to cushion children from their father's wrath, power and authority. In some cases, some wives also fear their husbands. This point is reiterated in Peter Godwin's book, The Fear: Robert Mugabe and the Martyrdom of Zimbabwe. The author writes, 'I know the leadership of Africa: a father is a figurehead... All radical fathers want to dominate their wives and kids... you do not want people to answer back...' (Godwin 2010:21). Children are expected to answer, 'Yes, ma'am' or 'Yes, sir'. The point is also well demonstrated in the case of RMG Independent End Time Message Church leader, Martin Gumbura of Zimbabwe, who "was feared so much that even his 11 wives would write individ- 
ual letters to him applying for permission to sit in the lounge and watch television, the court heard...' (allafrica.com, December 2013). This is an extreme example of fear associated with leadership roles at family level. One would think that the eleven wives of Gumbura were many enough to subdue him but it seems they could not afford to revolt for they were intimidated by both the man's position as the head of the family and his role as the founder and head of a religious community.

In most cases, people's fear of leaders becomes heightened as they begin to deal with people of higher ranks such as leading political figures and chiefs. They perceive such leaders as having control over their welfare and progress. For instance, in traditional settings, chiefs are most feared for they usually 'possess mystical, life-sustaining powers, with their own well-being intimately intertwined with the well-being of their people, lands, and institutions' (Olupona 2014:38). Therefore, such leaders are venerated and feared much more than family heads and village leaders, and not many people would dare challenge or oppose them for fear of consequences such as banishment from the community and land.

\section{Fear and Political Leadership in Zimbabwe}

Interestingly, as people cross from traditional leadership to formal leadership in politics, economics and various other spheres some tend to carry over the traditional view of chieftainship and seek to be feared like chiefs. Some use fear through brute force and power associated with their offices to ensure allegiance. For example, it was reported that, after losing the constitutional referendum in 2000, president Robert Mugabe quickly 'called for general elections, while setting off security forces and youth militia on a campaign of violence and intimidation to force the electorate to return Zanu (PF) to power' (The Zimbabwean April 24, 2014). One can argue that such a move was unnecessary because, in the light of Eurocentric values of democracy and political leadership, every leader with the people's interests at heart would naturally 'accept defeat', and would be willing 'to step aside for respect of voluntary followership' and let the band-wagon go on without him or her (Respondent Chizanga 2014).

On the contrary, propelled by various personal interests such as the desire to retain privileges tied to the office as well as the religio-cultural view of being 'a lifetime chief', Mugabe could not relinquish power just like that. In a similar discussion, Gordon (2002:169) writes that 'African leaders seem to be operating with two souls; one is an African soul and the other, their European colonial and neo-colonial soul'. If this is the case, it means some African leaders approach leadership with a double mandate. On the one hand, they desire to see a European style of democracy prevailing, and on the other, the leaders' inherent African quest for lifetime power may influ- 
ence their actions and perceptions of political or any other forms of leadership.

From the time of the 2000 referendum, soon after the opposition party the Movement for Democratic Change (MDC) was formed in 1999, many Zimbabweans in the opposition group reportedly felt insecure and some had to leave the country in the same way that some lawbreakers and opponents of chiefs and kings faced banishment from the land in traditional settings. The only difference was that in the political scene, the opponents fled for their lives before being asked to leave by the ruling party. In fact, the Zimbabwe Situation (15 August 2013) reported that during the 2013 presidential elections, many traditional leaders were manipulated by some politicians who understood the relevance of traditional power and authority. For instance, "headman Chinyamukwakwa of Chipinge South was reported for threatening villagers that they will be evicted from the area if they vote MDC' (Zimbabwe Situation 2013). Evidently, the headman acted the way he did to please the political leaders and he indeed had the authority to evict the people.

Another issue is that traditional leaders such as chiefs and fathers do not retire from their offices, and to disappoint them would be tantamount to becoming their long-term enemies. Therefore, when political leaders begin to see themselves as traditional leaders, chances are that they would not think of retiring or leaving office. To leave office will be a sign of weakness, total failure and complete loss of control. Interestingly, when president Robert Mugabe was asked during a televised interview if he would run for another term in office, he responded by flexing the muscle of his arm and asking rhetorically, 'At this age, I can still go some distance, can't I?' (Windhoek Observer 27 February 2014). As if to confirm his leadership mandate, many political speeches and songs refer to him as Baba (Father) Mugabe, while others call him Mudhara wedu ('our elder'). It seems these are more than just honorific terms because 'if he is indeed the people's father or elder, why and how would anybody think of a replacement while he is still alive? Would such attitude not tantamount to wishing the father an early death?'

Thus, because Mugabe perceives political leadership from a traditional leadership perspective, his relationship with his office reflects the maxim 'till death do us part'. Even when challenged by famous people such as the prominent religious leader bishop Desmond Tutu of the neighboring South Africa, president Robert Mugabe refused to be moved. In fact, bishop Tutu called Robert Mugabe 'a cartoon figure of an archetypal African dictator, who should resign or risk trial at the International Criminal Court' ( $B B C$ News 22 July 2010), but his words were ignored. 
Although it is easy to focus on the fear that leaders instill in their followers, it is interesting to note that sometimes leaders also have their own internal fears to contend with, as the following section shows.

\section{The Leader's Own Fears}

Fear associated with leadership, which is prevalent in the Zimbabwean society, has much to do with the leaders' fears. In Zimbabwe, there is the prevailing belief that most leaders are often surrounded by enemies from both the physical and the spiritual realm. Hence, leadership candidates ought to be 'fenced up', covered or protected. It is therefore not surprising that many leaders learn to seek protection through concoctions, holy water, oil, prayers, etc., depending on their religious beliefs. Some leaders continue to threaten and abuse their followers due to their own fears, part of which could be the fear of failure.

\section{Fear of Failure}

Some leaders at different levels of the society use fear probably because of their own 'fear of failure'. Like the fictitious character Okonkwo in the book Things Fall Apart by Chinua Achebe, some leaders often end up becoming brutal even to the followers they love the most because of the fear of failure. As evident throughout the book, Okonkwo was afraid of becoming a failure like his father whom he perceived as a lazy person and 'a failure', and of whom he notes, 'but his whole life was dominated by fear, the fear of failure and of weakness... and as a result he ruled his household with a heavy hand' (Achebe 1994:13). This shows that Okonkwo used fear because of his own fears.

Okonkwo's kind of fear is often replayed among the Shona and Ndebele people of Zimbabwe. For instance, some fathers may be very much afraid of poverty and lack of success to the point that they end up acting as slave drivers to their beloved wives and children on the farms while others even threaten to disown their children if they dare embarrass or disappoint them by failing in school. It is common to hear parents say to their children, 'Ukafoira usadzoke pano', literally 'if you fail your examinations do not come back home' or 'Ukamitiswa ugare ikoko', meaning 'if you get pregnant out of wedlock do not come back'. Therefore, for fear of being disowned, some children would work extra hard to impress their parents while others become frustrated due to their failure and become rebellious. However, Tony Hare has pointed out that it is 'a weak leader that will allow the fear to rule' (Hare 2003:32); yet some leaders like Okonkwo are practically under the power of fear even though they believe that they are strong and on top of their situation. Yet, another form of fear is the fear of losing power. 
Fear of Losing Power

Some people in leadership may use fear to validate their position as leaders probably to send a warning to enemies and potential enemies. For instance, since Zimbabwe got its independence in 1980, president Robert Mugabe has maintained the reputation of using brutal force to bring down his potential enemies and rivals. His behavior may have been connected to his own fear of losing grip on power. Godwin (2011) notes that within the first three years of independence, Mugabe ordered his troops in the Southern provinces of Matabeleland to launch Operation Gukurahundi, 'The Rains that Clear out the Chaff'. With that, he shattered Joshua Nkomo's ZAPU party before inviting him [Nkomo] to form a 'Unity Accord' in 1987, which effectively created the one-party state he had always wanted.

Before and after almost all general elections which took place after the year 2000, many people were beaten up and some lost their lives in the government's bid to teach them a lesson on how 'to vote well' next time. In fact, during and after the 2008 elections, through the informal operation Makavhotera $p a p i^{8}$ (literally 'whom did you vote for?') many people lost their lives, health, or property. Most people especially those residing in rural areas suspected of having voted for candidates of the opposition party became victims of this punishment or 'disciplinary measure'. Still others were forced to make public confessions that they were misled and were now returning home (kudzoka kumusha) - in this case, musha (home) refers to the ruling party, ZANU PF, a party that is led by those who brought the masses from colonial bondage to freedom.

Thus, because of his leadership style that is associated with fear, president Mugabe has been described by some scholars as an autocrat or one who 'is dictatorial yet taking little or no cognizance of the opinions or wishes of others' (Boon 2007:74). With this type of leadership, 'people are never empowered, and they rely entirely on the leader' (Boon 2007:1). In other words, people are continually at the mercy of the autocrat who in most cases would not want to leave office for, among other things, the fear of losing power or personal paranoia that if anyone else takes over, he or she may invalidate the 'gains of the liberation struggle'. Actually, one of Mugabe's infamous political dictums is 'Zimbabwe will never be a colony again' and it appears any other leader or political party that does not have its roots in the struggle for independence is suspected to be working against this view. Af- 
ter all, it is well-known in Zimbabwe that the liberation war heroes and war veterans including the president himself have always believed that 'the gun rather than diplomacy or the pen (ballot) is the only way to change the status quo' (Norman 2003:74). In their view, anyone who is not a liberation war hero does not qualify to lead Zimbabwe.

However, many people believe that for the above and many other reasons, the subject of presidential succession has remained a hot potato in Zimbabwean politics. In fact, one of the independent media, New Zimbabwe observed that 'Mugabe has used his entire political prowess to keep the party under his feet. By splitting, appeasing and blocking different factions, he has preserved unity and avoided military rebellions, civil unrest or challenges to his leadership' (March 27, 2014).

At any rate, it appears presidential succession is not yet one of those easy subjects in Zimbabwean politics, and the idea of seeking change through 'mass protests' does not seem to work in the country. According to Chiroro (2005), 'protest is an unattractive option for most Zimbabweans, as the likely wrath of the ZANU PF government and its security forces makes it an extremely dangerous position'. Such brutality can be attributed to the 'fear of losing grip on power'. It appears, at this point, that most people may choose not to participate in protests for 'fear of possible consequences'.

Nonetheless, one of the reasons some political leaders are cautious about the idea of losing power could be connected to the subject of charismatic authority. The theory of charismatic authority very much characterizes Zimbabwean leadership, both socially and politically. Thus, the next section focuses on the notion of charismatic authority, its manifestation in Zimbabwean politics in the past, as well as its impact on the local people's perception of leading and following.

\section{Charismatic Authority in Zimbabwe}

In view of the above discussion, I consider charismatic authority to be a leadership theory that best describes the leadership terrain in Zimbabwe especially in the political arena. The way religio-culture informs the practice of leading and following in the country is in line with Max Weber's view of charismatic authority. Weber (1980:227) shows that charismatic authority is largely driven or significantly propelled by the individual's special gift or charisma, which is believed to be the fundamental factor in the transformational process. The ruler or leaders' ability to generate great symbolic power makes them to believe that they are legitimate. Hence, 'the bearer of charisma assumes the tasks appropriate to him (sic) and requires obedience and a following in virtue of his (sic) mission'. Weber (1980:227) further argues that, in this type of authority, 'one could remain master or leader for as long as he (sic) is able to retain the followers' recognition by giving proofs'. 
Additionally, in charismatic authority, the bearer of charisma might feel that he or she has the right to rule independent of the followers' will while ironically feeling that it is the duty of those to whom he or she is sent (the followers) to recognize this charismatic qualification (Weber 1980:227). This type of leader acquires authority and 'retains it only by proving his powers in real life' (Weber 1980:227). However, it appears that the idea of having to deliver places much burden on the leader who may end up using every available means, either positive or negative, to demonstrate his or her capability.

\section{Sampling Charismatic Authority through Robert Gabriel Mugabe's Leadership}

One could have cited some other examples but the case of president Robert Mugabe appears much more interesting. Mugabe's style of leadership fits the description of charismatic leadership. As I consider the example of $\mathrm{Mu}-$ gabe in this section, I will also try to show some of the challenges associated with charismatic authority in the Zimbabwean society.

At the Johannesburg Earth Summit of 2002, Mugabe took a swipe at Tony Blair. He told the British leader and all his listeners: 'we have fought for our land, we have fought for our sovereignty, small as we are we have won our independence and we are prepared to shed our blood... so Blair keep your England and let me keep my Zimbabwe' (Mail Online 28 March 2014). Both the content and manner of his speech demonstrated high zeal and charisma, and this way, Mugabe was in a way publicly wrestling with Zimbabwe's former colonial masters so that the nation can become free indeed. And by calling Zimbabwe his own ('my Zimbabwe'), he put himself up for unconditional 'obedience and following in virtue of his mission' (Weber 1980:227). This mission involves making sure that the colonialists which were defeated in 1980 would not bounce back and try to make Zimbabwe their 'colony again'.

The basic argument among Zimbabweans is, if Mugabe still has the valor and means to protect those whom he saved earlier it is then logical to assume that the followers owe him complete loyalty. By constantly referring to history as he did in a speech that reminds his followers of how and why he came into office, he strives to retain authority (Weber 1980:227). The rhetoric as noted above is, if Mugabe can still deliver, why would anyone think of replacing him?

In fact, Morgan Tsvangirai the leader of the original opposition party called Movement for Democratic Change (MDC) has often been called a traitor seeking to take the country back to the colonial masters, and an ambassador of Britain and the Westerners' puppet. Therefore, in Mugabe's circle, the view is that some enemies are still prowling around; but why 
should anyone or any ballot box remove the man with the fundamental vision from office when he can still deliver? This way, the legitimacy of political leadership ceases to have much to do with the followers' wishes but it is centered on the mission of the bearer of charisma. Thus, it was not a surprise that when Morgan Tsvangirai disputed the legitimacy of the 2013 presidential elections results, part of Robert Mugabe's response in a public speech was, '...forward ever, never will we go back on our victory. We know no defeat...' Those who cannot swallow defeat should just go and die. If they want to go hang it is their choice, but even dogs will not sniff at their carcasses' (Zimeye.org 2013).

With his charismatic authority, Mugabe not only poses to be a custodian of 'political freedom', he is also known for catering to the 'needs of everyday living' of his followers (Weber 1980:226). Machingura (2012) relates how the Mugabe led ZANU PF party denied the NGOs and other groups from feeding the people of Zimbabwe during campaign periods because the party claimed that only Robert Mugabe had the mandate to cater for the people. Machingura further notes that NGOs were told that 'the food aid from United Nations agencies was under Government's custodianship' (Machingura 2012:402).

Moreover, when some citizens began to agitate that his time as leader was up, that he was old and had nothing else to offer, in order to keep the fire of followership burning, "Mugabe ordered his party militia onto whiteowned farms to forcibly evict the owners and their workers. In Shona, it was called jambanja, a violent overthrow' (Godwin 2011:21). With this move, Mugabe tried to score some political points among his followers.

Again, in the past, Mugabe had the reputation of using force to bring down his potential enemies including all those that attempted to usurp his office. Many historians described how, within the first three years of independence, Mugabe ordered his troops in the Southern provinces of Matabeleland to launch Operation Gukurahundi, 'The Rains that Clear out the Chaff'. In this way, he crushed Joshua Nkomo's ZAPU party before inviting him [Joshua Nkomo] into a 'Unity Accord' in 1987. This, according to Godwin (2011:21), 'effectively created a one party state that he (Mugabe) had always wanted'.

In a fashion that uniquely brings together religio-culture and politics, Kadungure (2010:1) observes that Robert Mugabe was so desperately in need of re-election that he humbled himself to attend an annual gathering of an apostolic sect. Kadungure noted that such were desperate days and 'dictator Robert Mugabe dressed up in white apostolic sect robes and joined the Johane Masowe Passover ceremony' (July 21, 2010). It was also reported in a different medium, in the Nehanda Dandaro.com (July 13, 2013), that Mugabe and his wife, 'all dressed in apostles garments, no shoes as per 
church custom', attended a ceremony in which about 100000 Johane Marange Apostles gathered at their annual Passover at St Noah Church in Mafararikwa, Bocha in Manicaland'. The article recounts that in order to show Mugabe's despair about retaining his office, his wife Grace sat on the floor among the apostles, while only the president was sitting on a chair, accompanied by senior Zanu PF officials such as Webster Shamu and resident minister Chris Mushowe.

Therefore, in light of such actions, it appears the idea of leading and staying in power is important to charismatic leaders. They would do whatever is necessary to stay in power. As long as they believe that they have a mission to accomplish, not many charismatic leaders would see the need to step down, step back or even retire.

\section{Analysis and Conclusion}

Considering the factors discussed above, the Zimbabwean concept of leadership appears to be very much intertwined with an indigenous way of life. In this context, there is an inherent quest to stay in office on the part of formal leaders as demonstrated by the life of Robert Mugabe. In Zimbabwe, leadership is inseparable from religious matters as some leaders especially politicians often seek ride on the crest of religion in order to garner political support. Apparently, the traditional view of leadership associated with roles such as fatherhood and chieftaincy seems to play a significant role in shaping the face of leadership in the society, and many people tend to carry this over into their professional lives.

Therefore, in the context of power, followers end up fearing people in leadership positions to the point of following them religiously. To some tradition-oriented people, followers should not challenge authority unless they are practicing rebellion and are ready to face the full wrath of their leaders. Ultimately, the charismatic leadership theory that naturally feeds on the prevailing religio-culture in Zimbabwe very well describes the leadership style of some prominent local leaders such as Robert Mugabe.

However, it is undeniable that the concept of leadership in this society is largely leader-centric and followers are perceived mainly as subjects whose duty is simply to follow. Some leaders also selfishly employ fear as a weapon knowing that it causes more harm than good to the followers. They continue to destroy their followers' self-esteem and other important virtues by using fear for as long as they achieve their intended immediate results. Yet the question should be asked: should we or our children continue to embrace a leadership culture which yields only some short term results and which is acceptable only locally even though we know that our citizens now participate cross-culturally in business, work and play due to globalization and technological advancement? 
The former president of Zambia, Kenneth Kaunda, observed that 'Africa will rise or fall on the quality of its leadership' (Stith 2008:31). In the same vein, I believe that unless the people of Zimbabwe vote for positive change in terms of future leadership the social, economic, political, and religious challenges which are peculiar to Zimbabwe will continue to abound.

\section{Bibliography}

Adler R (2013) Interplay: The Process of Interpersonal Communication. New York, NY: Oxford University Press.

BBC News. 22 July 2010. 'Profile: Archbishop Desmond Tutu'. Accessed on 23 April 2014. http://www.bbc.com/news/world-africa-10725711.

Bhebhe M (2013) An African Culture of Multiple Religiosity: The Perspective of the Church of Christ in Zimbabwe. Saarbruecken: Lambert Academic Publishing.

Bhebhe M (2011) The Resilience of African Beliefs and Practices among the Urban Contemporary Africans: The Zimbabwean Story. Saarbruecken: Lambert Academic Publishing.

Boon M (2007) The African Way: The Power of Interactive Leadership. Cape Town: Zebra Press.

Brad J, Ken P (2011) Studying Leadership. Los Angeles, CA: Sage.

Bennis W (2009) On Becoming a Leader. New York, NY: Basic Books.

Berger J (1972) Ways of Seeing. London: Penguin Books.

Bourdillon MFC, eds (1977) Christianity South of the Zambezi. Volume 2. Gweru: Mambo Press.

Bowron B (1957) Literature and Covet Culture. American Quarterly 9(4): $377-386$.

Chiroro B (2005) Apathy Fatigue or Boycott? An Analysis of the 2005 Zimbabwe Senate Elections. EISA Occasional Paper 38: 1-16. Auckland Park, South Africa: Electoral Institute of Southern Africa.

Chizanga DF (2014) 'Leadership-fear and Change'. Telephone interview with the pastor and founder of Africa Development Mission Trust. Conducted on 30 March 2014.

Dusing S (2000) Traditional Leadership and Democratization in Southern Africa: A Comparative Study of Botswana, Namibia, and Southern Africa. New Brunswick, NJ: Transaction Publishers.

Ellis S, Ter Haar G (2004) Worlds of Power: Religious Thought and Political Practice in Africa. New York, NY: Oxford University Press.

Ferris K, Stein J (2010) The Real World: An Introduction to Sociology. Second Edition. New York, NY: Norton.

Gathogo J (2001) The Truth about African Hospitality: Is There Hope for Africa? Mombasa: The Salt. 
Geertz C (2000) The Interpretation of Cultures. New York, NY: Basic Books.

Goleman D (2000) Leadership that Gets Results. Harvard Business Review (March-April Issue): 79-90.

Gordon JU (2002) African Leadership in the Twentieth Century: An Enduring Experiment in Democracy. New York, NY: University Press of America.

Hall ET (1966) The Hidden Dimension. New York, NY: Anchor Books Doubleday.

Hallen B, Sodipo OJ (1997) Knowledge, Belief, and Witchcraft. Palo Alto, CA: Stanford University Press.

Hallowell AI (1938) Fear and Anxiety as Cultural and Individual Variables in a Primitive Society. The Journal of Social Psychology 9: 25-47.

Hare T (2003) Fear in Leadership: The Adrenaline Journey. Training Journal (March Issue): 30-32.

Hofstede G (1984) Culture's Consequences: International Differences in Workrelated Values. Newbury Park, CA: Sage.

Hunter MG, Tan FB (2008) Voluntary Turnover of Information System Professionals: A Cross-Cultural Investigation. Journal of Global Information Management 16(4): 46-66.

Kadungure N (21 July 2010) 'Mugabe in Desperate Attempt to Woo Apostolic Sect'. NehandaRadio.com. Accessed on 27 March 2014.

Laing S (2009) Fear, Worry, and Ritualistic Behavior in Childhood: Developmental Trends and Interrelations. Infant and Child Development. 18:351-366.

Linton RR (1938) Culture Society and the Individual. The Journal of Abnormal and Social Psychology 33(4): 425-436

Machiavelli N (1908) The Prince (written c. 1505), published 1515. Translated by Marriott WK.

Machingura F (2012) The Messianic Feeding Of The Masses: An Analysis of John 6 in the Context of Messianic Leadership in Post-Colonial Zimbabwe. Bamberg: Bamberg University Press.

Mail Online (2014) Mugabe 'Let me Keep My Zimbabwe'. Daily Mail. Published by Associated Newspapers Ltd. URL: http://www.dailymail.co.uk/news/article-136292/Mugabe-let-Zimbabwe.html. 28 March 2014.

Mbiti JS (1990) African Religions and Philosophy. Oxford: Heinemann.

Messick DM (2005) On the Psychological Exchange between Leaders and Followers. In Messick D, Kramer RM (eds) The Psychology of Leadership: New Perspectives and Research. New Jersey, NJ: Lawrence Erlbaum Associates.

Moran PR (2001) Teaching Culture: Perspectives in Practice. Boston, MA: Heinle.

PERICHORESIS 14.1 (2016) 
Moran RT (2011) Managing Cultural Differences: Leadership Skills and Strategies for Working in a Global World. Burlington, MA: ButterworthHeinemann.

Ndlovu JJM (1991) The Place of African Traditional Religious Heritage. Religious Education Curricula in Multi-faith Issues and Approaches in Religious Education with Special Reference to Zimbabwe. Utrecht: Rijksuniversiteit.

Ndlovu R (2013) Mugabe Blasts Tutu over Gay Rights' BDLive.com. Http://www.bdlive.co.za/africa/africannews/2013/07/29/mugabe-bla-ststutu-over-gay-rights. 25 April 2014.

Nehanda Dandaro.com (2014) PICTURES: Mugabe Hijacks Johane Marange Apostolic Church Pilgrimage. 13 July 2013. Accessed on 27 March 2014.

Oduyoye MA (2004) African Culture and African Development. A Christian Reappraisal. Journal of African Christian Thought 4(2): 21.

Olupona JK (2014) African Religions: A Very Short Introduction. New York, NY: Oxford University Press.

Platvoet CJ, Olupona JK, eds (1996) The Study of Religions in Africa Past, Present, and Prospects. Cambridge: Roots and Branches.

Purdon J (2011) Covert Culture. The Junket. Accessed on 25 April 2014. http://thejunket.org/2011/10/issue-one/covert-culture/.

Rupapa T (2013) Zimbabwe: Gumbura's Wives Applied to Watch TV, Court Told. 1 December 2014. Accessed on 21 December 2014.

Sarpong PK (2005) Can Christianity Dialogue with African Traditional Religion? Retrieved from: http://www.afrikaworld.net/afrel/sapo-ng.html. Accessed on 20 June 2005.

Srite M (2008) Does within-culture Variation Matter? An Empirical Study of Computer Usage. Journal of Global Information Management 16(1): 1-25.

Stagich T (2001) Collaborative Leadership and Global Transformation. Global Leadership Resources.

Stith CR, ed (2008) For such a Time as This: African Leadership Challenges. Boston, MA: APARC Press.

Suarez G (1993) Managing Fear in the Workplace. TQLO Publication No 9301.

The Zimbabwean. 24 April 2014. 'No Vote' a Blunder. For further details, see: http://www.-thezimbabwean.co/news/zimbabwe/54026/no-vote-a-blunderpm.html.

The Zimbabwean Situation 2014. Accessed on 31 January 2014.

Tuan YF (1979) Landscapes of Fear. New York, NY: Pantheon Books.

Weber M (1980) Selections in Translation. Cambridge: Cambridge University Press. 
Windhoek Observer (Ondjirio. Hijo) (2014) Gushungo at 90. Accessed on 25 April 2014. Further details on: http://observer24.com.na/opinionsanalysis/2997-gushungo-at-90.

Zimeye.org (2013) Mugabe Tells Tsvangirai to Go Hang. Accessed on 26 April 2014; http://www.zimeye.org/mugabe-tells-tsvangirai-to-go-hang/. 